\title{
SUCCESSION PLANNING AS A CRITICAL MANAGEMENT IMPERATIVE: A SYSTEMATIC REVIEW
}

\begin{abstract}
This paper conducted a systematic review of succession planning (SP) articles published over the last decade. The Systematic Quantitative Assessment Technique was used to identify 174 SP articles. The review covered five key issues: 1) Time distribution, 2) Geographic distribution, 3) Article type, 4) Data collection methods, and 5) Themes explored. The findings revealed that interest in SP fluctuated over the last decade, and that South America and Oceania were the least represented by SP scholarship. The spread between conceptual and empirical SP articles were skewed towards the former, and survey was the most popular data collection method. Five themes were identified, with the most striking finding being that that if the 'going concern' principle of organizations is to be achieved, management must make deliberate efforts to formalize the SP process with the clear understanding that it is a continuous, transparent and participatory process, and thus a crucial management imperative.
\end{abstract}

Keywords: Succession planning, Systematic review, Management imperative, Going concern.

\section{INTRODUCTION}

According to the 'going concern' principle of accounting, once an organization is established it is expected to continue to operate indefinitely unless there is evidence to the contrary (Savova, 2021). The reality of course is that these organizations are run by human beings who are anything but indefinite. As the saying goes, the only constants are death and taxes, and all human beings are destined to die at some point in time. The fragility and vulnerability of the lives of human beings has been brought into sharp focus by the ongoing COVID-19 global pandemic that has led to the death of over three million people in only a year and a half (World Health Organisation, 2021). Santora (2020, p.4) explains this phenomena eloquently as follows: "COVID-19 is an equal-opportunity, non-discriminating

\footnotetext{
${ }^{1}$ Anamege Anthonia Obianuju, MPhil Management, Nile University of Nigeria, Abuja, Nigeria; e-mail: anamege.pro@gmail.com (corresponding author). ORCID: 0000-0001-6526-5964.

${ }^{2}$ Umar Abbas Ibrahim, PhD, Nile University of Nigeria, Abuja, Nigeria; e-mail: abbas.ibrahim@nileuniversity.edu.ng. ORCID: 0000-0001-8273-9148.

${ }^{3}$ Umaru Mustapha Zubairu, PhD, Federal University of Technology Minna, Nigeria; e-mail: uzubairu@gmail.com. ORCID: 0000-0001-9498-233X.
} 
killer. It knows no boundaries, ages, genders, races, creeds, or religions". From an organizational sustainability point of view, the deaths caused by the COVID-19 pandemic has elevated the concept of succession planning up to the top of the list of global management consciousness (Firfiray, Gomez-Mejia, 2021). This is because the sudden demise of key personnel in organizations leads to a loss of invaluable corporate knowledge that can have devastating effects on the long-term survival of any organization particularly given how competitive and turbulent the global business landscape is (Arslan, 2021).

Succession planning refers to a deliberate and systematic process of ensuring the storage of valuable corporate knowledge needed for business continuity by identifying and grooming future leaders who can replace current leaders when they die, retire or leave the organization (Soares et al., 2021). This process, which is also known as 'replacement planning', typically begins through a thorough evaluation of the skill-sets of all senior members of management (Bano et al., 2021). This is followed by identifying members of middle management that have the potential of replacing senior management in the future (Bano et al., 2021). These potential replacements are then trained to develop and hone the skills necessary for them to step into leadership positions when the situation calls for it (Bano et al., 2021). The succession planning process is thus a continuous one rather than a one-time activity; it requires annual updating and re-evaluating in response to the current happenings in the organization's internal and external environment (Hayden et al., 2021).

A well-executed and formalized succession planning process is expected to provide several benefits to an organization. Firstly, when succession is based on transparent and merit-based criteria, it can serve as a great motivational tool among employees who can see a clear path to advancement within the organization; this in turn empowers them to work harder and can lead to increased job satisfaction (El Badawy et al., 2016). Secondly, a clear succession plan also encourages senior members of management to become mentors and teachers to their younger counterparts as a deliberate strategy of transferring knowledge and expertise which contributes greatly to business continuity (Weisblat, 2018). Thirdly, a formalized succession plan enables the organization to properly measure the value each employee provides, and this makes internal promotions much easier (Best, 2016). Fourthly, as the current leadership crop of baby boomers begin to retire, a new generation of leaders will be needed in the very near future, and having a formal succession plan means that an organization is ready to deal with this inevitable reality (Martin, O'Shea, 2021). Finally, from the point of view of shareholder-owned organizations, having a formal succession plan gives shareholders confidence that experienced people are being groomed to ensure the smooth running of the business if and when something happens to the current leadership (Sain, Koul, 2020).

Given the critical importance of succession planning (SP) for the long-term sustainability of an organization, this paper conducted a systematic review of the last decade of scholarship on this important management imperative so as to answer five research questions: 1) Has scholarly interest in SP increased or decreased over the last decade, 2012-2021? 2) What has been the geographical distribution of SP scholarship over the last decade? 3) Has the focus of SP scholarship being conceptual or empirical? 4) What data collection methods have been used in SP scholarship in the last decade? 5) What themes have extant SP scholarship explored in the last decade? These questions were answered via a thorough review of 174 succession planning articles published by reputable academic journals in the last ten years. 
The rest of the paper proceeds as follows: First the method adopted by this paper in conducting its systematic review of SP scholarship is presented. This is followed by a presentation and discussion of the results and of the output of the systematic review as it relates to this paper's five research question. Discussions of identified research gaps are also included in this section. The paper ends with a concluding section which summarizes the key findings of the review, the paper's limitations and recommendations for future SP systematic reviews.

\section{METHOD}

This paper utilized the systematic quantitative assessment technique (SQAT) developed by Pickering and Byrne (2014) to conduct a systematic review of SP scholarship over the last ten years, 2012-2021. The SQAT recommends a five-step process for conducting an effective systematic review: 1) Define your topic, 2) Formulate your research questions, 3) Identify key words, 4) Identify and search databases and 5) Read and assess publications.

For this study, the topic was simply "success planning articles published in the last ten years", while five research questions were formulated as follows: 1) Has scholarly interest in SP increased or decreased over the last decade, 2012-2021? 2) What has been the geographical distribution of SP scholarship over the last decade? 3) Has the focus of SP scholarship being conceptual or empirical? 4) What data collection methods have been used in SP scholarship in the last decade? 5) What themes have extant SP scholarship explored in the last decade?

Table 1. SP articles reviewed categorized by academic database

\begin{tabular}{|c|l|c|}
\hline S/N & \multicolumn{1}{|c|}{ Database } & Number of SP articles \\
\hline 1. & African Journals Online & 1 \\
\hline 2. & Citeseer & 6 \\
\hline 3. & Elsevier & 15 \\
\hline 4. & Emerald & 27 \\
\hline 5. & Harvard & 1 \\
\hline 6. & HeinOnline & 18 \\
\hline 7. & IGI-Global & 8 \\
\hline 8. & Inderscience & 6 \\
\hline 9. & JSTOR & 2 \\
\hline 10. & Kluwer & 2 \\
\hline 11. & Oxford & 3 \\
\hline 12. & Sage & 30 \\
\hline 13. & Springer & 2 \\
\hline 14. & SSRN & 17 \\
\hline 15. & Taylor and Francis & $\mathbf{1 7 4}$ \\
\hline 16. & Wiley & \\
\hline & & TOTAL \\
\hline
\end{tabular}

Source: own study. 
In order to search for relevant articles, "succession planning" served as the key phrase to guide the search process on Google Scholar. Sixteen reputable academic databases were selected from which relevant articles on SP were selected. In total, 174 SP articles published in the last decade were selected for review in this study and Table 1 presents the breakdown of these articles based on academic database; the search for articles concluded on April 30, 2021 and thus SP papers published after that data were not captured by the review.

The next section of the paper presents the findings of the systematic review as it relates to each of the five research questions formulated in this paper.

\section{RESULTS AND DISCUSSION}

\subsection{Has scholarly interest in SP increased or decreased over the last decade, 2012-2021?}

Figure 1 presents the number of SP articles published in the 16 databases utilized for this review. In order to answer this paper's first research question, the number of papers published in 2021 are not considered as only articles published in the first quarter were considered.

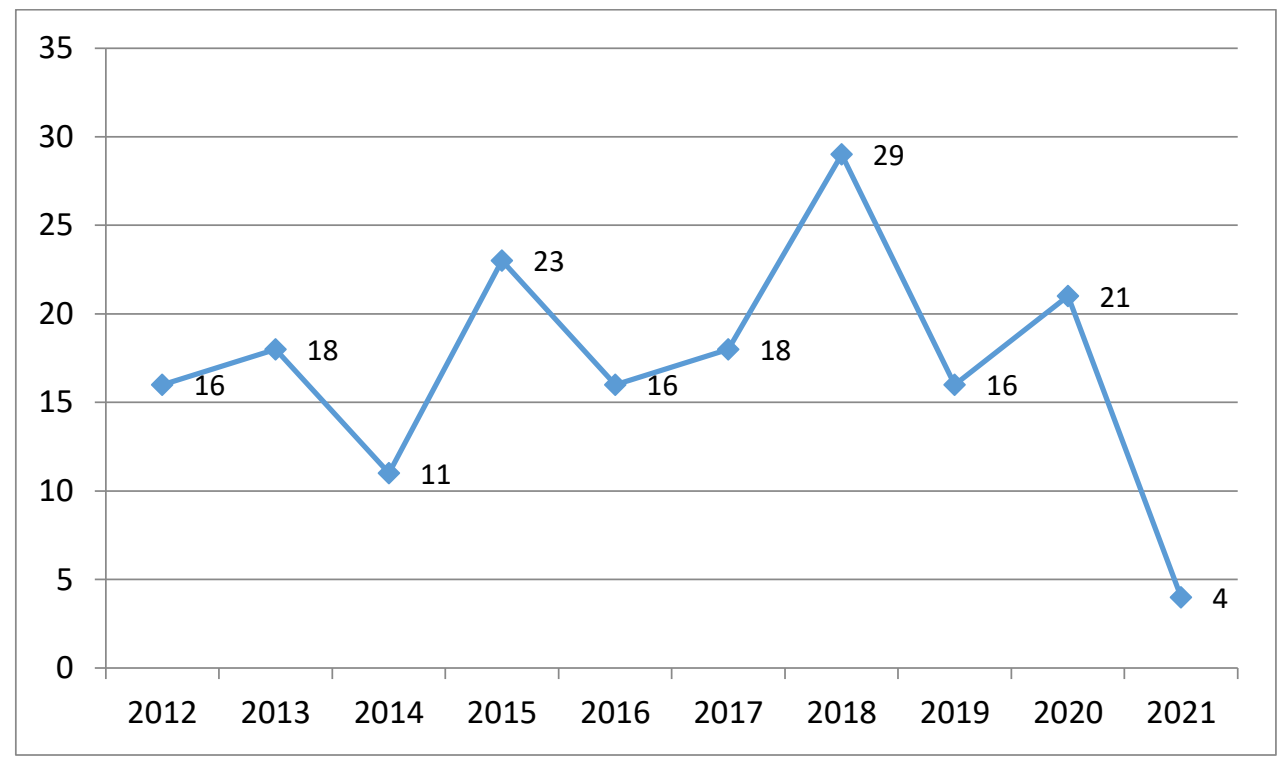

Figure 1. Time distribution of SP articles published over the period, 2012-2021

Source: own study

It can be observed that scholarly interest in SP has waxed and waned over the ten-year period covered by this systematic review. Discounting 2021 which is incomplete, the peak of scholarly interest in SP was attained in 2018 with 29 articles published while the lowest output was in 2014 with only 11 articles published in the whole of that year. The year 2020 was the last complete year considered in this review, and $21 \mathrm{SP}$ articles were published in the 16 databases considered in this paper. 


\subsection{What has been the geographical distribution of SP scholarship over the last decade?}

In this section, the geographical distribution of SP scholarship is presented in two categories, continent by continent distribution and then a country by country distribution. Figure 2 presents the continent by continent distribution of the SP articles reviewed in this paper.

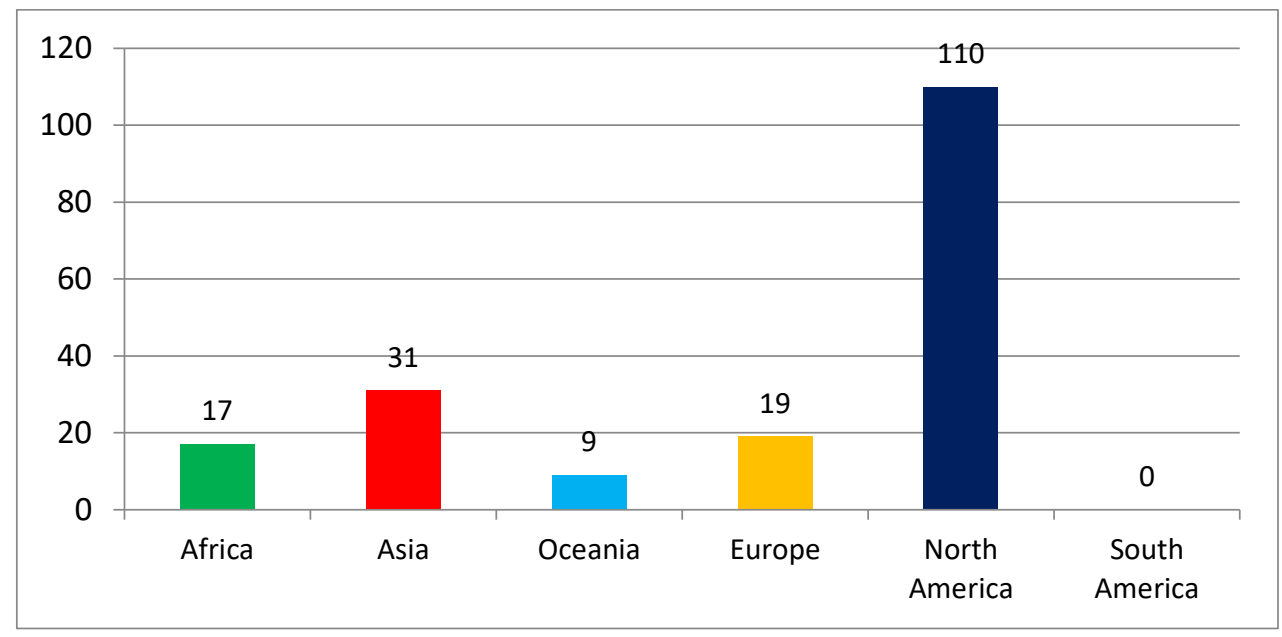

Figure 2. Distribution of articles by continent

Source: own study.

It can be observed from Figure 2 that North America had by far the largest number of SP articles reviewed in this paper with 110 . Asia was a distant second with 31 , followed by Europe with 19 and Africa with 17. Oceania had 9 articles while South America had no representation. There are 13 countries in South America and it is surprising that no SP article reviewed in this paper emanated from any of these countries. One might argue that it is because the languages spoken and written in these countries are typically Spanish or Portuguese and this paper only concentrated on SP articles written in English. However, this argument does not hold water as Asia had the second most SP articles and countries in this continent do not have English as their mother tongues. The obvious recommendation for future research based on the findings shown in Figure 2 is that more SP research has to be done in South America so as to provide perspective as to how SP occurs in the countries that make up the continent. This research gap is particularly pertinent considering the fact that since the beginning of the global COVID-19 pandemic, there has been an increase in the number of South American businesses seeking professional support in the establishment of formal succession plans (Wealthadviser, 2021).

From a country perspective, 39 different countries had at least one SP article, and Figure 3 presents the five countries with the most SP articles in this review. The United States of America was by far the most represented country in this review with 101 SP articles. India had less than a tenth of the number of American-based SP articles with 10, followed by Australia with 9 and the United Kingdom with 6 articles. Canada rounded up the top 5 SP 
countries with 5 articles. Table 2 presents the remaining 34 countries arranged in descending order based on the number of SP articles from each country.

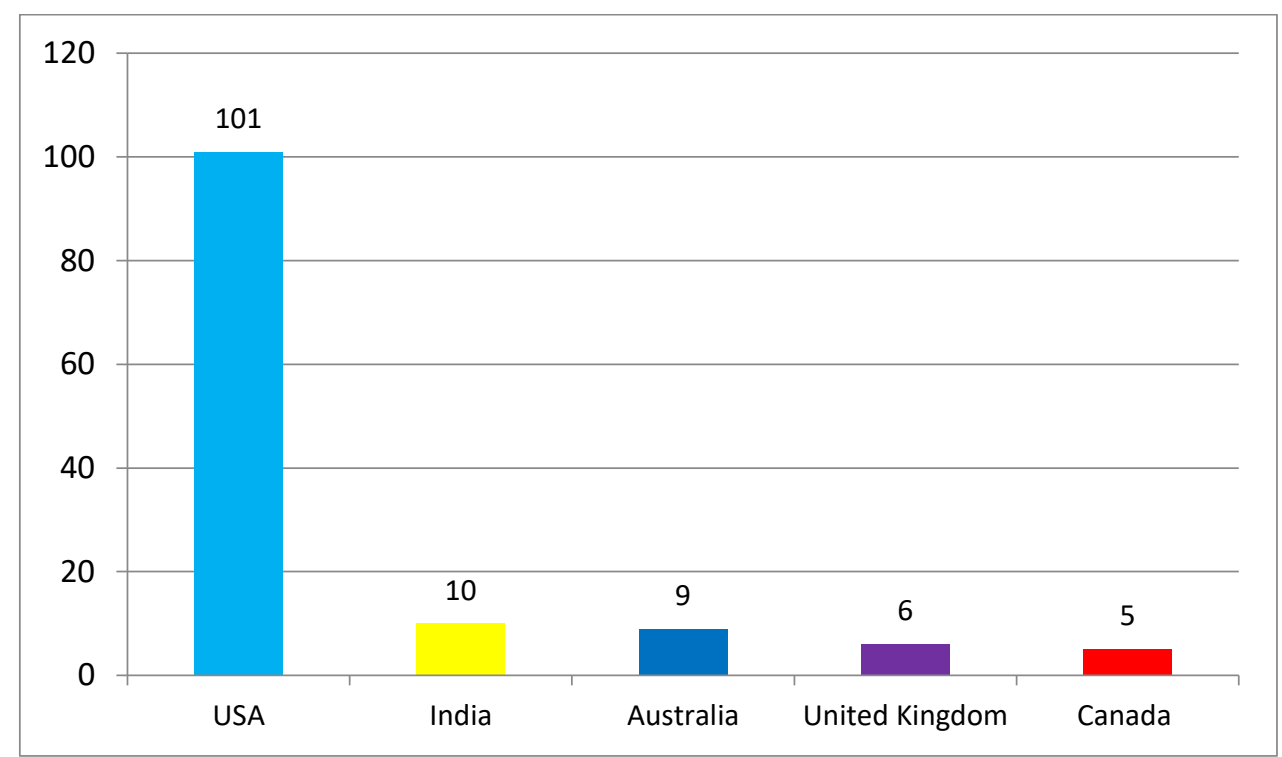

Figure 3. Five countries with the most SP articles

Source: own study.

Table 2. Remaining 34 countries with at least one SP article

\begin{tabular}{|c|l|c||c|l|c|}
\hline S/N & \multicolumn{1}{|c|}{ Country } & $\begin{array}{c}\text { Number of SP } \\
\text { articles }\end{array}$ & S/N & Country & $\begin{array}{c}\text { Number of SP } \\
\text { articles }\end{array}$ \\
\hline 1. & Nigeria & 4 & 18. & Israel & 1 \\
\hline 2. & Pakistan & 4 & 19. & Italy & 1 \\
\hline 3. & South Africa & 4 & 20. & Kenya & 1 \\
\hline 4. & China & 3 & 21. & Kosovo & 1 \\
\hline 5. & Egypt & 3 & 22. & Lebanon & 1 \\
\hline 6. & Belgium & 2 & 23. & Mexico & 1 \\
\hline 7. & Germany & 2 & 24. & Morocco & 1 \\
\hline 8. & Iran & 2 & 25. & Portugal & 1 \\
\hline 9. & Jamaica & 2 & 26. & Scotland & 1 \\
\hline 10. & Kuwait & 2 & 27. & Spain & 1 \\
\hline 11. & Malaysia & 2 & 28. & Sudan & 1 \\
\hline 12. & Tanzania & 2 & 29. & Sudan & 1 \\
\hline 13. & Vietnam & 2 & 30. & Sweden & 1 \\
\hline 14. & Croatia & 1 & 32. & Switzerland & 1 \\
\hline 15. & Cuba & 1 & 33. & Thailand & 1 \\
\hline 16. & France & 1 & 34. & United Arab Emirates & \\
\hline 17. & Ghana & 1 & & & \\
\hline
\end{tabular}

Source: own study. 
According to Worldometer, there are 195 independent countries that constitute Planet Earth. In this SP review, only 39 of these 195 countries were represented which indicates that over the last ten years covered by this review, English-based SP scholarship has only proliferated $20 \%$ of countries in the world. The remaining $80 \%$ provide fertile ground for future SP scholars to explore as all these countries have businesses that practice succession planning in some form or another.

\subsection{Has the focus of SP scholarship been conceptual or empirical?}

For this paper, conceptual papers referred to those SP papers that provide view points or recommendations on how SP could be developed or improved upon in different kinds of organization; these articles did not collect any form of data but rather relied on the opinions of the authors. On the other hand, all SP articles that involved any form of data collection were categorized as empirical articles. Based on this classification, Figure 4 presents the classification of the $174 \mathrm{SP}$ articles reviewed in this paper based on whether they were conceptual or empirical.

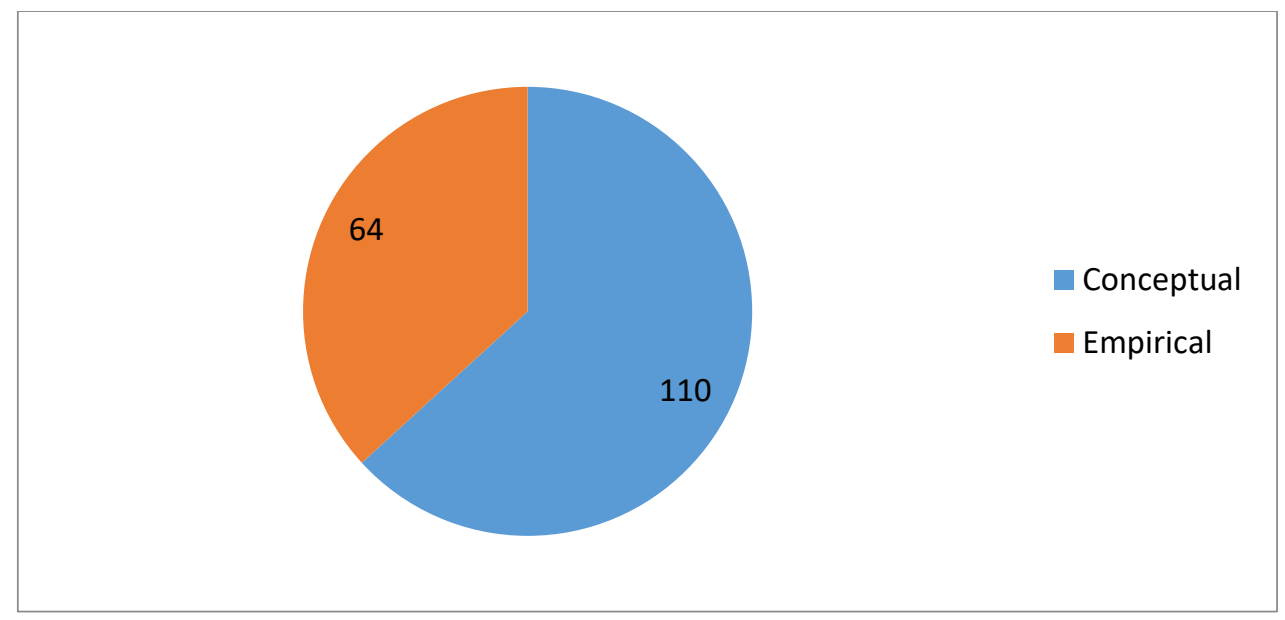

Figure 4. SP articles by type (conceptual vs. empirical)

Source: own study.

Figure 4 shows that the majority of the SP articles revealed (110 out of $174 ; 63 \%)$ were conceptual in nature with the authors providing different explanations as to why SP was important for the long-term sustainability of organizations (e.g., Spina, Spina, 2020; Tietjen-Smith et al., 2020; Bakare, 2021). These articles also provided recommendations on how to formalize, improve and enhance the SP process (e.g., Creta et al., 2020; LeCounte, 2020; Opute, 2020). On other hand, 37\% of the articles reviewed (64 out of 174) sought to assert the efficacy of some of these recommendations in organizations via the collection and analyses of different kinds of data (Arslan, 2021; Lu et al., 2021; Phillips, 2021).

Figure 4 indicates an obvious imbalance in extant SP scholarship in the last decade with suggested SP ideas far surpassing the actual empirical testing of these ideas. Future SP 
researchers should thus focus more on validating the many scholarly SP suggestions and recommendations that have been put forward by current scholars.

\subsection{What data collection methods have been used in SP scholarship \\ in the last decade?}

In answering this research question, only the 64 empirical SP articles identified in the previous subsection were considered as they are the ones that actually collected any form of data. Figure 5 presents the nine different data collection strategies adopted by these 64 articles.

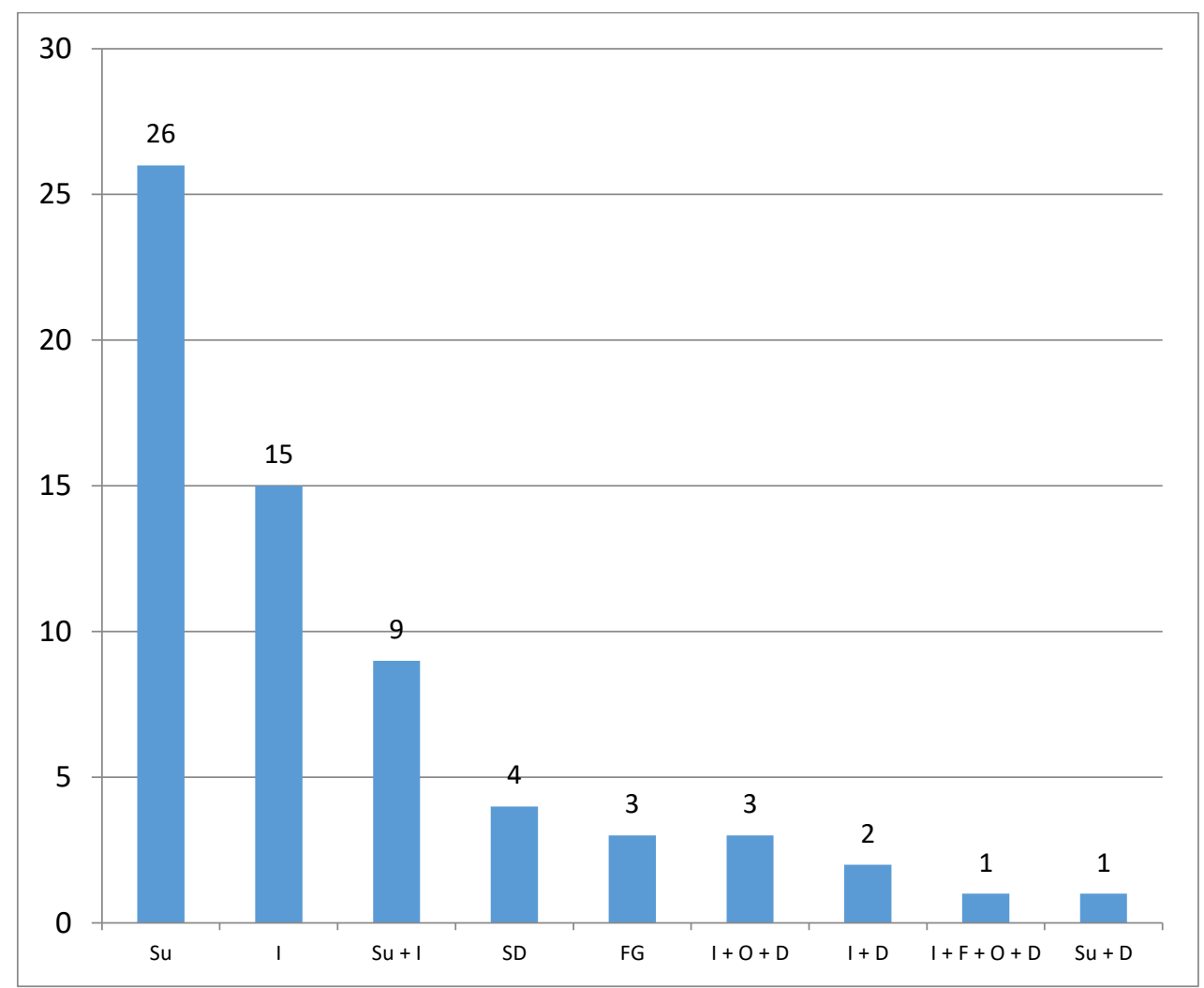

Key: Su - Survey; I - Interviews; SD - Secondary Data; FG - Focus Group; O - Observation; D - Document Analysis

Figure 5. Data collection strategies used by 64 SP articles

Source: own study.

Figure 5 indicates that six distinct data collection methods were utilized by the 64 empirical SP articles reviewed in this paper: i) Survey, ii) Interview, iii) Secondary Data, iv) Focus Group, v) Observation and vi) Document Analysis. It also indicates that a majority of the 64 articles (44 out of 64) relied on a single data collection method while the rest of 
the articles (20 out of 64) relied on a mixed methods approach utilizing some combination of the six distinct data collection methods.

Surveys alone were the most popular data collection method utilized with 26 of the 64 articles reviewed using this strategy (e.g., Kiwia, 2019; Umans et al., 2020; Urban \& Nonkwelo, 2020). Interviews alone were the next most common method, with 15 of the 64 articles adopting this strategy (Goldman, 2020; Okoro \& Iheanachor, 2020; Arslan, 2021). Nine of the articles combined both surveys and interviews (e.g., Ntshangase et al., 2016; Huynh et al., 2017; Lu et al., 2021) while four articles relied only on secondary data (von Drathen, 2014; McConnell \& Qi, 2018; Peter-Hawkins et al., 2018; Tao \& Zhao, 2019 ). Three articles combined interviews, observations and document analysis (Loomis, 2018; Barton, 2019; Matias \& Franco, 2020) while another three articles adopted focus groups to collect relevant SP data (Collins, 2015; Chang \& Besel, 2020; Perrenoud, 2020). Two of the articles reviewed combined interviews with document analysis (Cole \& Harbour, 2015; Tucker, 2020) while one article combined a survey with document analysis (Carter et al., 2019. Vito (2018) had the most robust data collection strategy combining four different methods (interviews, focus groups, observation and document analysis) whilst conducting a multiple case study of SP with the data collection objective being to achieve data triangulation.

As mentioned earlier, Figure 5 shows that $69 \%$ (44 out of 64) empirical SP articles relied on only one method of data collection, either qualitative or quantitative. Each broad method of data collection has its strength and weaknesses, and the more robust approach is to combine both qualitative and quantitative data collection methods so that the strengths of both approaches can help to mitigate the weaknesses of the other (Christofi et al., 2021). Future SP scholarship should thus adopt a mixed methods approach so that data triangulation can be achieved, following the example of Vito (2018).

\subsection{What themes have extant SP scholarship explored in the last decade?}

Five distinct themes were explored by the 174 SP articles reviewed in this study: 1) Assessing the level of SP in different contexts, 2) Challenges to SP implementation, 3) SP and organizational performance, 4) SP and corporate knowledge and 5) SP and management/employee outcomes. Figure 6 provides information regarding the number of articles that focused on each of these five themes.

Figure 6 indicates that more than half (93 out of 174, 53\%) of the articles reviewed sought to determine the level of SP being practiced in different organizational contexts. Specifically these articles explored seven different contexts (family businesses [34], education [27], healthcare [22], not-for-profit organizations [4], law firms [4], an accounting firm and a public sector organization).

\section{Theme 1: Assessing the level of SP in different contexts}

$\mathrm{SP}$ in family businesses was found to be very unique relative to its occurrence in nonfamily businesses particularly because the potential successor was more often than not a relative who was decades younger than the incumbent (Sharma et al., 2015; Ntshangase et al., 2016; LeCounte, 2020). Family business owners had different motivations for engaging in SP (family harmony and business continuity) (Gilding et al., 2013; Grable et al., 2015; Okoro, Iheanachor, 2020). However, most of these businesses did not have formal or written succession plans (Seaman et al., 2013; Jain, Jain, 2014; Alrubaishi, 2017). Due to this deficiency, a vast majority of family businesses do not even reach the second 
generation of continuity; only about $10 \%$ get to the third generation (Giuliani, 2016; Vincent, 2017; Umans et al., 2020).

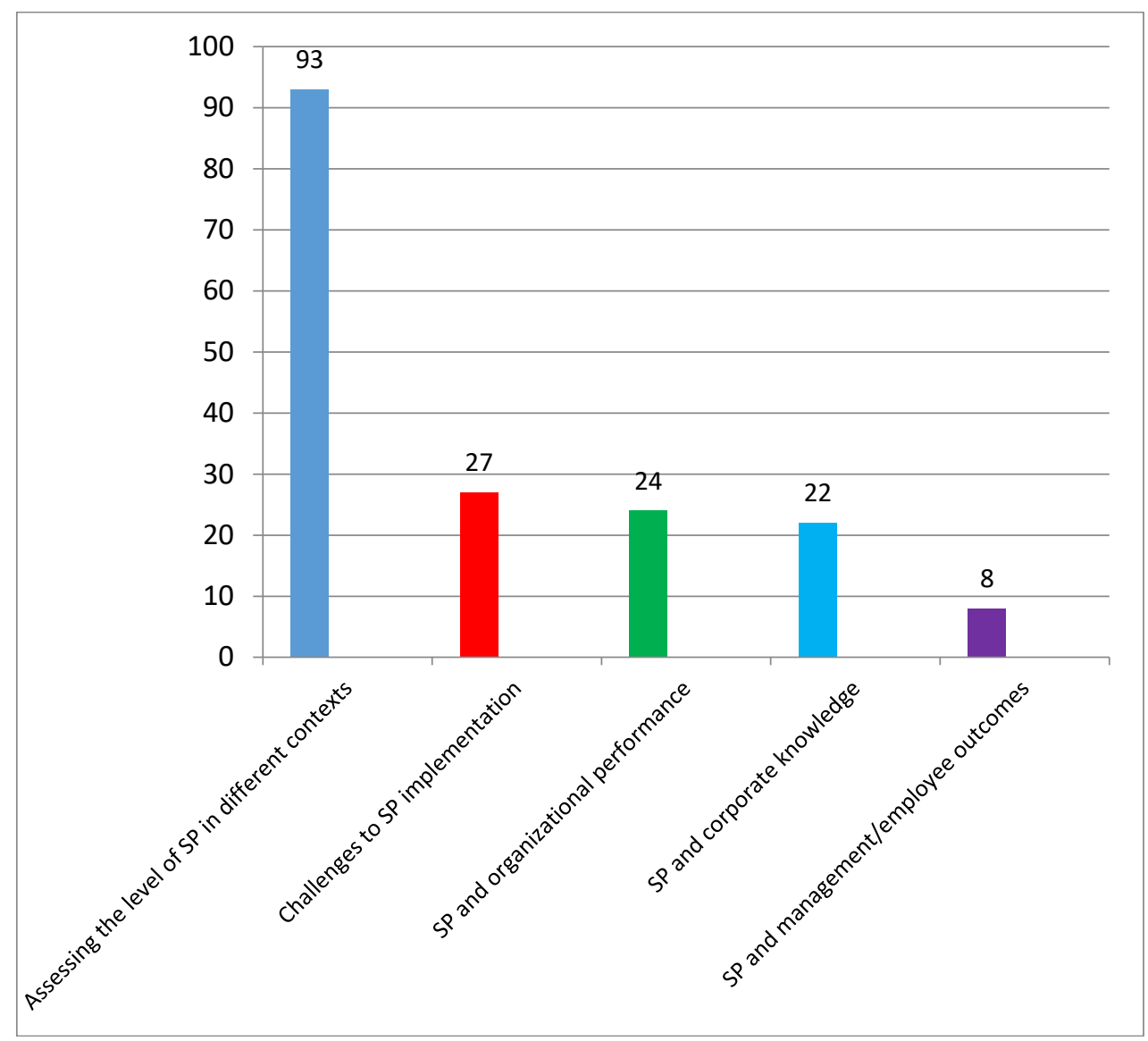

Figure 6. SP themes explored by 174 articles reviewed

Source: own study.

Continuing with the discussion of SP in family businesses, country differences existed in the level of SP in family businesses (Lussier, Sonfield, 2012; Gowthami, 2015). Varying succession laws were found to be an important cause of these differences (Harrison, 2012; Mulder, 2012; Richman, 2012). Cultural practices could also explained country differences in SP practice (Nicholson, Lashley, 2016; Menezes et al., 2019); for example Arab-owned family businesses were found to practice more formal SP practices than their US counterparts (Sonfield et al., 2015). Another example was the fact that some cultures tend to favour males over females as potential successors (Ramadani et al., 2017; Urban, Nonkwelo, 2020). Family dynamics was also identified as a third determinant of the level of SP practiced by family businesses in different countries (Arslan, 2021; Lu et al., 2021). 
In order to overcome the challenges of SP in family businesses, several recommendations were made. Ackerman (2013) found that employee stock ownership plans were effective in overcoming taxation issues when implementing a succession plan for family businesses. Seeking the opinion of trusted advisors were also found to play a critical role in the establishment and success of SP in family businesses (Michel, Kammerlander, 2015; Graham, Mischel, 2019; Umans et al., 2019). A third recommendation was the appointment of external planning consultants can help create effective SP for family businesses (Staehr, 2015; Lillico, 2016; Hall, 2017; Moja, 2019; Mihaylov, Zurbruegg, 2020). Ultimately, a bottom-up participatory approach to SP was proposed as the optimum strategy for family businesses (Hibbler-Britt \& Wheatley, 2018; Matias, Franco, 2020).

The second most explored context in this theme was the educational sector. Similar to the case of family businesses, it was found that SP was not well established in educational institutions (Klein, Salk, 2013; Huynh et al., 2017; Peter-Hawkins et al., 2018). The shared governance system practiced by these institutions where a board of trustees were tasked with running the institutions were found to be a major obstacle to SP as such boards were often resistant to change (Klein, Salk, 2013; Goldman, 2020). It was recommended that these educational institutions (EI) make SP a priority in order to develop a pool of potential successors in key positions (Russell, Sabina, 2014; Simpson, West, 2014; Knapp et al., 2017; Siewert, Louderack, 2019). In other words, SP must become an important of an EI's organizational culture (Hall-Ellis, 2015; Huynh, 2016; Rayburn et al., 2016; Ritchie, 2020). The yearly performance appraisal system can be co-opted as a SP strategy to identify candidates with leadership potential (McLean et al., 2016). Once these potential leaders are identified, extensive mentoring and training programmes can be utilized to hone and enhance their leadership competencies (Tietjen-Smith et al., 2020; Tucker, 2020; Phillips, 2021).

The importance of SP for long-term sustainability must be doubly emphasized in the educational administration curriculum (Charbonneau, Freeman, 2016; Fusarelli et al., 2018; Green, 2018; Melton, 2018; Phillips, 2020). Ensuring ethnic diversity in the pool of potential successors can also enrich the SP process in EI (Kumaran, 2015). Additionally, technology can be a useful tool to store important knowledge as a part of the SP process (Sobel, Drewry, 2015; Yucedag-Ozcan, Metcalfe, 2018). Contrary to the majority support for SP in EIs, Weare (2015) argued that it is not the right approach for academic libraries as it leads to the risk of perpetuating obsolete ideas of the incumbents. He argues that each vacant role should be filled with the most skilled applicant on a case by case basis (Weare, 2015).

The healthcare sector represented the third most explored organizational context in this first theme. Like the family business and educational sectors, scholars also found that SP was not well established in the healthcare sector (Titzer et al., 2013; Cole, Harbour, 2015; Richins, 2018; Vito, 2018). In fact, a 2016 national survey of local health departments in America revealed that only $39.5 \%$ of these departments had a formal succession plan (Darnell, Campbell, 2016). It was strongly recommended that healthcare institutions be proactive in developing formal SP strategies so as to reduce employee turnover in the health sector, particularly when recruiting numbers have been declining over the years (Trepanier, Crenshaw, 2013; Ellinger et al., 2014; Acree-Hamann, 2016; Donner et al., 2017; Phillips et al., 2018; Sierra, Calabrese, 2019).

With the millennial generation set to replace the baby boomer generation as the largest proportion of the workforce, healthcare institutions must ensure that the SP process is 
transparent and collaborative; two characteristics that matter a lot to the millennial generation (Kosterlitz, Lewis, 2017; Payne et al., 2018; Chang, Besel, 2020). These Millennials also have a duty to educate their managers on the importance of incorporating SP as crucial part of the long-term sustainability of the health sector (Raftery, 2015; Reeves, 2018; Ruffin, 2018). An effective SP strategy could be simulation which could equip nurses with the leadership qualities needed to succeed current leaders (Waxman, 2014). Internships can also provide professionals with leadership potential with hands-on experience for the future (Selig, 2020).

Healthcare institutions need to transition from succession planning to succession management; the latter concept envisions SP as an ongoing process rather than a one-time or 'as-needed' organizational process (Turner, 2018; Creta et al., 2020). Similar to Weare (2015) in the educational sector, Anderson (2018) was the sole dissenting voice against SP in the health sector. She argued that SP in this sector tended to favour men over women as the male-dominant leadership tended to identify males like themselves as the best candidates for succession. She concluded that looking for successors outside the organization would provide a more level playing field for women in the health sector.

Four of the 93 articles in this first theme explored the level of SP among not-for-profit organizations (Gothard, Austin, 2013; Bozer et al., 2015; McKee \& Froelich, 2016; Varhegyi, Jepsen, 2017). Gothard and Austin (2013) opined that there was no single best approach to SP in non-profit organizations. However, top management's proactive involvement in the SP process is crucial for its success (Bozer et al., 2015). A major obstacle to successful SP in this sector is its inclination to continuity (McKee, Froelich, 2016). Another obstacle is that boards of non-profit organization lack the expertise, time and resources to implement a comprehensive SP strategy (Varhegyi, Jepsen, 2017).

Another four articles focused on the level of SP among law firms (Best, 2016; Griggs, 2016; Gallagher, 2017; Mitchell, 2017). Like other organizational context discussed in earlier paragraphs, SP was also not prevalent in law firms, with a 2015 survey revealing that only $31 \%$ of law firms in the US had formal succession plans (Griggs, 2016). This was considered worrisome when one considered that most senior partners in law firms were part of the baby boomer generation who have already retired or are set to do so in a few years time (Griggs, 2016; Gallagher, 2017). An important component of successful SP in law firms was the integration of technology that allowed firms to track the productivity of their senior partners so that the most important partner's succession can be prioritized (Best, 2016). The process of transferring clients from one attorney to another was identified as crucial component of SP in the law firm (Gallagher, 2017). Unfortunately many senior partners in law firms were unwilling to discuss their own mortality and the consequent need for a formal succession plan (Mitchell, 2017).

Wadeson and Ciccotosto (2013) focused on determining the level of SP among accounting firms while Al-Suwaidi et al. (2020) focused on public sector organizations. The former study found that formal SP strategies were considered not feasible by owners of the firms due to changing work expectations of accountants and differences in thinking between the baby boomers and the younger generation of accountants; the latter study discovered that the organizational culture of a public sector organization was one of the most important determinants of the presence of a formal succession plan in such an organization. Relative to the private sector, SP in the public sector is grossly under-researched and thus provides an interesting area for future scholarship to concentrate on. 


\section{Theme 2: Challenges to SP implementation}

27 of the 174 SP articles (16\%) all sought to identify the challenges or obstacles that were hampering organizations from successfully establishing and implementing a formal and comprehensive SP strategy. The first major obstacle was an inability of managers to translate their perception of SP as important into effective SP practice (Galbraith et al., 2012; Garg, Van Weele, 2012; Brooks, 2014; Cook, 2014; Wright, 2015). This inability dubbed by Heitner (2012, p. 53) as "planning paralysis" was caused by managers seeing retirement as too far into the future (Koltin, 2012; Church, 2014; Kjellander, 2018). This paralysis was further exacerbated by the fact that many managers failed to understand that SP is not only for retirement; it is useful for guarding against employee turnover or even sudden death of key personnel (Goodwin, Graebe, 2017; Schaeffer \& Akhavan, 2017; Bratcher. 2018; Wilson, 2018). Another cause of the planning paralysis was the fact that managers simply did not consider SP as critically important in the context of operating their businesses successfully on a daily basis (Muhoho, 2014; Bottomley, 2018; Loomis, 2018).

Besides the planning paralysis, conflict between the incumbent and potential successor was identified as a huge impediment to effective SP; the case of Ratan Tata (the incumbent) and Cyrus Mistry (the successor) of Tata Group in India was a case in point (Yadav, Shankar, 2017; Budhiraja, Pathak, 2018). To overcome these impediments, SP must be considered as an important part of a broader talent management strategy meant to ensure that the organization continues to run smoothly regardless of what happens to key personnel (Nyberg et al., 2019; Page, Gerstberger, 2019; Perrenoud, 2020).

\section{Theme 3: SP and organizational performance}

24 of the 174 SP articles reviewed (14\%) investigated the impact of SP on the performance of organizations. They discovered that SP impacts business survival if the successor is capable, possesses entrepreneurial orientation and has been mentored and trained properly (Gumbo et al., 2012; Zepeda et al., 2012; Capuano, 2013; Farthing, 2013). In addition, SP positively impacts organizational outcomes if the following antecedents are present, visionary leadership and a formal leadership development process (Titzer, Shirley, 2013; Kundanis, 2014; Muslim et al., 2015; Sherrer, Rezania, 2020).

The business case for SP was further strengthened with the finding that businesses with formal succession plans outperformed those without formal succession plans (Tan-Atichat, Aiyeku, 2013; Harrell, 2016; Sharma, Sengupta, 2018; Tao, Zhao, 2019). Similarly, SP had a positive effect on a company's adaptability and dynamic capability thus providing it with an important competitive advantage over its rivals (Akani, 2015). This translated into positive impact on its financial performance and non-financial performance (Mokhber et al., 2017; Hosseini et al., 2018; McConnell, Qi, 2018; Wendee et al., 2018). Finally, firms successors selected by the founder outperformed firms where the successors were selected by other family members indicating that SP was an important strategic decision that should be carried out by the CEO rather than being delegated (Kiwia et al., 2019).

\section{Theme 4: SP and corporate knowledge}

22 of the 174 SP articles reviewed (13\%) evaluated the effective of SP in preventing the loss of valuable corporate knowledge among organizations. "Corporate knowledge is the combined tacit, tribal, documented and undocumented knowledge that has been gained within a corporation. This knowledge goes to provide the information and knowledge by which an organization runs" (Carey, 2015). Apparently dealing with current issues has 
prevented management from investing in SP as a strategy to stop corporate knowledge loss (Schiuma et al., 2012; Pandey, Sharma, 2014; Opute, 2020). However, the global COVID-19 pandemic has brought CEO mortality into sharp focus which has heightened the importance of protecting corporate knowledge through formal SP strategies (Santora, 2020). In order to ensure the long term sustainability of their organizations, senior employees are willing to share and transfer knowledge with younger employees as long as there is transparency in the SP process (Applebaum et al., 2012; Winship, 2012; Fitsimmons, 2013; Chithambo, 2018; Weisblat, 2018).

An important question to ask is what strategy should firms utilize in effectively ensuring that corporate knowledge is not lost? Ethnography has been identified as an effective SP strategy whereby corporate knowledge is stored by observing, recording and analyzing the actions of older, high performing individuals (Gentry, 2013; Bakare, 2021). The ethnography approach can be strengthened through the use of technology-enabled knowledge repositories (Durst \& Aggestam, 2017).

Another strategy that has been proposed is the conducting of a skills-gap assessment of the current workforce so as to identify competencies that need to be enhanced for future leadership positions (Clark, 2015; Hildebrand, 2015; Newhall, 2015; Johnson, 2018; Keller, 2018). This skills-assessment gap should be carried out at least ten years before the incumbent is due to retire as this allows time for a smooth and easy transition of leadership and assets (Koeberle-Schmid, Escher, 2018; Spina, Spina, 2020). A third strategy to secure valuable corporate knowledge is the adoption of an employee rotation system where employees are trained on different aspects of the job thus developing a multi-talented workforce (Sprague, 2019).

\section{Theme 5: SP and management/employee outcomes}

Only eight of the 174 SP articles reviewed investigated the influence of SP on various management and employee outcomes. All eight articles found that SP had a significant and positive impact on various management and employee outcomes. For example, SP was found to have a significant positive effect on CEO turnover (von Drathen, 2014; Carter et al., 2019). In the same vein, the more comprehensive the succession plan in an organization, the more satisfied executives were with the leadership transition process (Perrenoud, Sullivan, 2017).

Regarding employee outcomes, a clearly defined SP (clear selection criteria, clear rewards and clear organizational structure) had a positive impact on employee satisfaction (Farashah, 2015). Similarly, SP was found to have a positive correlation with employee job satisfaction and engagement (El Badawy et al., 2016; Ali, Mehreen, 2019). SP also led to an enhanced feeling of job security and positive employee attitudes while reducing employee turnover intentions (Ali, Mehreen, 2019). Finally, SP also had a positive impact on employee performance (Ali et al., 2019).

As mentioned previously, Hibbler-Britt and Wheatly (2018) as well as Matias and Franco (2020) all identified a bottom-up participatory approach as the most effective strategy for holistic SP in organizations. It is thus surprising that only 5\% of the SP articles investigated the impact of SP on the most important stakeholders in the entire process, the incumbent managers and their potential successors. This lack of attention given to these stakeholders by extant SP scholarship reviewed in this paper presents an important research gap which future SP researchers should investigate more thoroughly. The need to address this important research gap is further accentuated by the fact that the world is currently in 
the Knowledge Worker Age where human capital is considered the most important resource for the long term sustainability of all businesses (Laallam et al., 2020; Zeidan, Itani, 2020; Iliescu, 2021).

\section{CONCLUSION}

This paper provided an extensive review of the 174 SP articles published in the last decade in order to answer five research questions, each one dealing with the time distribution of these articles, their geographical distribution, the type of articles published, the data collection methods utilized and the major themes explored. The review revealed that interest in SP has ebbed and flowed over the last ten years and that North America has been the most fruitful continent in terms of SP research. The review also revealed that a majority of the SP articles reviewed were conceptual in nature, with survey being the most commonly used data collection method for the relatively few empirical studies conducted in this area. Six themes were explored by the $174 \mathrm{SP}$ articles reviewed with the assessment of the level of SP in different organizations being the most commonly explored theme, while the impact of SP on management and employment outcomes was the least explored theme.

Although this review tried to accommodate as many SP articles as possible by utilizing articles published by 16 reputable publishers, it is still limited by the fact that it does not contain all SP articles published in the last decade. Future reviews can adopt a more robust approach by widening the search horizon for SP articles and also by including the number of years covered by the review in order to provide a more comprehensive picture of the research journey undertaken by SP scholarship over the years.

This review of SP scholarship has revealed that if the 'going concern' principle of organizations is to be achieved, management must make deliberate efforts to formalize the SP process with the clear understanding that it is a continuous, transparent and participatory process, and thus a crucial management imperative.

\section{REFERENCES}

Ackerman, D. (2013). Using an ESOP in Business Succession Planning. "J. Passthrough Entities", 16.

Acree-Hamann, C. (2016). A call to action: Succession planning needed. "Newborn and Infant Nursing Reviews", 16(3).

Akani, V. C. (2015). Management succession planning and corporate survival in Nigeria: A study of Banks in Portharcourt. "Management", 7(27).

Al Suwaidi, M., Jabeen, F., Stachowicz-Stanusch, A., Webb, M. (2020). Determinants Linked to Executive Succession Planning in Public Sector Organizations. "Vision”, 24(3).

Ali, Z., Mehreen, A. (2019). Understanding succession planning as a combating strategy for turnover intentions. "Journal of Advances in Management Research". DOI: 10.1108/JAMR-09-2018-0076.

Ali, Z., Mahmood, B., Mehreen, A. (2019). Linking succession planning to employee performance: The mediating roles of career development and performance appraisal. "Australian Journal of Career Development", 28(2).

Alrubaishi, D. A. (2017). Succession planning in family SMEs in Saudi Arabia: A descriptive study. Access on the internet: https://link.springer.com/chapter/10.1007/978-3-319-57630$5 \_12$ 
Anderson, C. L. (2018). The Feminist Perspective of Implicit Bias in Succession Planning in Healthcare. Access on the internet: https://link.springer.com/chapter/10.1007/978-3-31972532-1_12

Appelbaum, S. H., Benyo, C., Gunkel, H., Ramadan, S., Sakkal, F., Wolff, D. (2012). Transferring corporate knowledge via succession planning: Analysis and solutions-Part 2. I"ndustrial and Commercial Training", 44(7).

Arslan, M. (2021). Succession Planning in Family-Owned Business Evidence From an Emerging Economy. Access on the internet: https://www.igi-global.com/chapter/ succession-planning-in-family-owned-business-evidence-from-an-emerging-economy/ 262329

Bakare, A. (2021). Succession Planning as a Developmental Tool for Sustainability. Access on the internet: https://www.igi-global.com/chapter/succession-planning-as-a-developmentaltool-for-sustainability/262773

Bano, Y., Omar, S. S., Ismail, F. (2021). Revitalising Organisations' Emergency Succession Planning in the Face of the Covid-19 Outbreak. "The European Journal of Social \& Behavioural Sciences”. DOI: 10.15405/ejsbs.285.

Barton, A. (2019). Preparing for leadership turnover in Christian higher education: Best practices in succession planning. "Christian Higher Education", 18(1-2).

Best, S. J. (2016). Using Technology to Benefit Succession Planning. "Law Prac.”, 42.

Bottomley, K. S. (2018). Developing sustainable leadership through succession planning. Access on the internet: https://link.springer.com/chapter/10.1007/978-3-319-72532-1_1

Bozer, G., Kuna, S., Santora, J. C. (2015). The role of leadership development in enhancing succession planning in the Israeli nonprofit sector. "Human Service Organizations: Management, Leadership \& Governance”, 39(5).

Bratcher, P. (2018). Succession Planning. "J. New Librarianship”, 3.

Brooks, S. (2014). Strategic, future-proof succession planning connects Telefónica with success: How HR was able to move the process on. "Human Resource Management International Digest", 22(2).

Budhiraja, S., Pathak, U. K. (2018). Dynamics of succession planning for Indian family-owned businesses: learning from successful organizations. "Human Resource Management International Digest", 26(4).

Capuano, T. A. (2013). Achieving succession planning and implementation: one healthcare network's story. Access on the internet: https://journals.sagepub.com/doi/abs/10.1016/ j.hcmf.2013.06.003

Carey, C. (2015). Corporate Knowledge is a Corporate Asset. Access on the internet: http://www.compendian.com/2015/01/corporate-knowledge-is-a-corporate-asset\#: : text $=$ If $\% 20$ the $\% 20$ individual $\% 20$ having $\% 20$ that,knowledge $\% 20$ or $\% 20$ experience $\% 20$ to $\% 20$ use

Carter, K. M., Gonzalez-Mulé, E., Mount, M. K., Oh, I. S., Zachar, L. S. (2019). Managers moving on up (or out): Linking self-other agreement on leadership behaviors to succession planning and voluntary turnover. "Journal of Vocational Behavior", 115.

Chang, C. Y., Besel, K. (2020). Cultivating next generation of healthcare leaders in Havana: Barriers and recommendation for succession planning. "International Journal of Healthcare Management", 1-9.

Charbonneau, D. H., Freeman, J. L. (2016). Succession planning for libraries. "Journal of Library Administration", 56(7). 
Chithambo, L. (2018). Succession Planning Research Within the Business/IT Arena. Access on the internet: https://link.springer.com/chapter/10.1007/978-3-319-72532-1_10

Christofi, M., Hadjielias, E., Hughes, M., \& Plakoyiannaki, E. (2021). Advancing Research Methodologies in Management Scholarship. "British Journal of Management”. Access on the internet: https://onlinelibrary.wiley.com/pb-assets/assets/14678551/BJM\%20 Call\%20for\%20Papers\%20Advancing\%20Research\%20Methodologies-1613746482.pdf

Church, A. H. (2014). Succession planning 2.0: Building bench through better execution. "Strategic HR Review", 13(6).

Clark, D. K. (2015). Comprehensive succession planning: Preparing the next generation for success. "Journal-American Water Works Association", 107(8).

Cole, S. L., Harbour, C. P. (2015). Succession planning activities at a rural public health department. "The Qualitative Report”, 20(1).

Collins, L., Murray, B., McCracken, K. (2015). Succession planning in William Jackson Food Group. "Journal of Family Business Management", 5(1).

Cook, E. L. (2014). Sole Practitioner Succession Planning: It Is Time to Stop Recommending Action and Start Requiring It. Ohio St. Entrepren. Bus. LJ, 9.

Creta, A. M., Gross, A. H. (2020, May). Components of an Effective Professional Development Strategy: The Professional Practice Model, Peer Feedback, Mentorship, Sponsorship, and Succession Planning. Access on the internet: https://www.sciencedirect.com/science/ article/pii/S0749208120300395

Darnell, J. S., Campbell, R. T. (2015). Succession planning in local health departments: results from a national survey. "Journal of Public Health Management and Practice”, 21(2).

Donner III, E. M., Gridley, D., Ulreich, S., Bluth, E. I. (2017). Succession planning and management: the backbone of the radiology group's future. "Journal of the American College of Radiology", 14(1).

Durst, S., Aggestam, L. (2017). Using IT-Supported knowledge repositories for succession planning in SMEs: how to deal with knowledge loss? Access on the internet: https://www.igi-global.com/chapter/using-it-supported-knowledge-repositories-forsuccession-planning-in-smes/171754

El Badawy, T. A. E., Alaadin, Y., Magdy, M. M. (2016). Succession planning, job engagement and job satisfaction: the missing link. "Middle East Journal of Management", 3(1).

Ellinger, L. K., Trapskin, P. J., Black, R., Kotis, D., Alexander, E. (2014). Leadership and effective succession planning in health-system pharmacy departments. "Hospital pharmacy", 49(4).

Farashah, A. D. (2015). Strategic fit framework of succession planning: Effects on career attitudes and career success. "International Journal of Human Resources Development and Management", 15(2-4).

Farthing, K. (2013). Succession planning: the right people in the right positions at the right time. Access on the internet: https://journals.sagepub.com/doi/full/10.1310/hpj4803-175

Firfiray, S., Gomez-Mejia, L. R. (2021). Can family firms nurture socioemotional wealth in the aftermath of Covid-19? Implications for research and practice. BRQ Business Research Quarterly, 23409444211008907.

Fitsimmons, G. (2013). Collective succession planning in librarianship. "The Bottom Line”, 26(4). 
Fusarelli, B. C., Fusarelli, L. D., Riddick, F. (2018). Planning for the future: Leadership development and succession planning in education. "Journal of Research on Leadership Education", 13(3).

Galbraith, Q., Smith, S. D., Walker, B. (2012). A case for succession planning: How academic libraries are responding to the need to prepare future leaders. "Library management", 33(4/5).

Gallagher, S. P. (2017). The Changing Face of Succession Planning. “Law Prac.”, 43.

Garg, A. K., Van Weele, E. (2012). Succession planning and its impact on the performance of small micro medium enterprises within the manufacturing sector in Johannesburg. "International Journal of Business and Management", 7(9).

Gentry, K. M. (2013). Ethnography and the "Age Wave": Knowledge capture for succession planning. Access on the internet: https://anthrosource.onlinelibrary.wiley.com/doi/ abs/10.1111/j.1559-8918.2013.00025.x

Gilding, M., Gregory, S., Cosson, B. (2013). Motives and outcomes in family business succession planning. "Entrepreneurship Theory and Practice", 39(2).

Giuliani, P. A. (2016). The Seven Deadly Sins of Succession Planning. GPSolo, 33.

Goldman, C. (2020). Structure, culture, and agency: Examining succession planning in California State University (CSU) Libraries. “Journal of Library Administration”, 60(1).

Goodwin, G. C., Graebe, S. F. (2017). Mentoring and Succession Planning. Access on the internet: https://link.springer.com/chapter/10.1007/978-3-319-45877-9_22

Gothard, S., Austin, M. J. (2013). Leadership succession planning: Implications for nonprofit human service organizations. "Administration in Social Work", 37(3).

Gowthami, C. (2012). Succession planning a need or a necessity - A global perspective. "International Journal of Management, IT and Engineering”, 2(9).

Grable, J. E., Goetz, J. W., Valentino, K. (Eds.). (2015). Business Succession Planning. CFP Board Financial Planning Competency Handbook

Graham, E., Mischel, L. (2019). Continuing the Legacy at Nordic Lodge: Succession Planning at an Iconic Family-Owned Restaurant. "Entrepreneurship Education and Pedagogy", 2(3).

Green, M. P. (2018). Leaders in the making: Succession planning starts in library school. “J. New Librarianship”, 3.

Griggs, J. D. (2016). Overcoming the Succession Planning Conundrum. “Law Prac.”, 42.

Gumbo, C.O., Ngugi, J.K., Gakure, R.W., \& Ngugi, P.K. (2012). Roll of Succession Planning on Survival of Small and Medium Family Enterprises after Retirement/Death of the First Generation Entrepreneurs in Kenya. "International Journal of Business and Social Research", 2(6).

Hall, S. A. (2017). Farm to Market: Planning Succession for Family Farmers. “GPSolo”, 34(5).

Hall-Ellis, S. D. (2015). Succession planning and staff development - a winning combination. "The Bottom Line", 28(3).

Harrell, E. (2016). Succession planning: what the research says. "Harvard Business Review”, 94(12).

Hayden, M. T., Mattimoe, R., Jack, L. (2021). Sensemaking and the influencing factors on farmer decision-making. "Journal of Rural Studies", 84.

Heitner, M. (2012). A Psychiatrist's Guide to Succession Planning. “Prob. \& Prop.”, 26. 
Hibbler-Britt, L. M., Wheatley, A. C. (2018). Succession Planning in Family-Owned Businesses. Access on the internet: https://link.springer.com/chapter/10.1007/978-3-319-72532-1_7

Hildebrand, U. (2015). Succession planning. Access on the internet: https://link.springer.com/ chapter/10.1007/978-3-662-43553-3_26

Hosseini, S. H., Barzoki, A. S., Isfahani, A. N. (2018). Analysis of the effects of succession planning implementation on organisational performance. "International Journal of Productivity and Quality Management”, 25(2).

Huynh, T. T. (2016). Library succession planning process in Vietnam. "New Library World", $117(11 / 12)$.

Huynh, T. T., Reynolds, S., Mercieca, P. (2017). Succession Planning in Vietnamese Libraries: Challenges and Solutions. Access on the internet: https://link.springer.com/chapter/ 10.1057/978-1-137-57940-9_21

Iliescu, A. N. (2021). The Emergence of Knowmads from the Knowledge Workers. "Management Dynamics in the Knowledge Economy", 9(1).

Jain, S. K., Jain, N. (2014). Business succession planning in Indian MSM-FOBEs: A study based on managerial-role employees. "Global Business Review", 15(3).

Johnson, R. D., Pepper, D., Adkins, J., Emejom, A. A. (2018). Succession planning for large and small organizations: "A practical review of professional business corporations. Succession planning”.

Keller, J. (2018). Succession planning management. Access on the internet: https://link. springer.com/chapter/10.1007/978-3-319-72532-1_4

Kiwia, R. H., Bengesi, K. M., Ndyetabula, D. W. (2019). Succession planning and performance of family-owned small and medium enterprises in Arusha City-Tanzania. "Journal of Family Business Management”, 10(3).

Kjellander, D. M. (2018). Succession Planning in the Small Business: The Good and the Bad. Access on the internet: https://link.springer.com/chapter/10.1007/978-3-319-72532-1_6

Klein, M. F., Salk, R. J. (2013). Presidential succession planning: A qualitative study in private higher education. "Journal of Leadership \& Organizational Studies", 20(3).

Knapp, K. M., Wright, C., Clarke, H., McAnulla, S. J., Nightingale, J. M. (2017). The academic radiography workforce: age profile, succession planning and academic development. "Radiography", 23.

Koeberle-Schmid, A., Escher, J. (2018). Succession Planning. Access on the internet: https://link.springer.com/chapter/10.1007/978-3-319-99085-9_6

Koltin, A. D. (2012). Best Practices on Succession Planning. “CPA Prac. Mgmt. F. ”, 8.

Kosterlitz, M., Lewis, J. (2017). From baby boomer to millennial: Succession planning for the future. "Nurse Leader", 15(6).

Kumaran, M. (2015). Succession planning process that includes visible minority librarians. "Library Management", 36(6/7).

Kundanis, B. (2014). Succession planning and the library: The strategic plan. Access on the internet: https://www.igi-global.com/chapter/succession-planning-and-the-library/99510

Laallam, A., Kassim, S., Adawiah, E. R., Saiti, B. (2020). Towards knowledge-based waqf organizations. Access on the internet: https://www.igi-global.com/chapter/towardsknowledge-based-waqf-organizations/244766

LeCounte, J. F. (2020). Founder-CEOs: Succession planning for the success, growth, and legacy of family firms. "Journal of Small Business Management". 
Lillico, P. (2016). Tax and Succession Planning for the Family Cottage. "Est. Tr. \& Pensions $J$.", 35.

Loomis, S. G. (2018). Federal agency succession planning. Access on the internet: https://link.springer.com/chapter/10.1007/978-3-319-72532-1_8

Lu, F., Kwan, H. K., Ma, B. (2021). Carry the past into the future: the effects of CEO temporal focus on succession planning in family firms. "Asia Pacific Journal of Management".

Lussier, R. N., \& Sonfield, M. C. (2012). Family businesses' succession planning: a sevencountry comparison. "Journal of Small Business and Enterprise Development”, 19(1).

Martin, C. M., O'Shea, K. (2021). Succession planning for organizational stability. "Nursing Management", 52(4).

Matias, C., Franco, M. (2020). The role of the family council and protocol in planning the succession process in family firms. "Journal of Family Business Management". Advance Online Publication. DOI: 10.1108/JFBM-01-2020-0004

McConnell, J. J., Qi, Q. (2018). Does CEO Succession Planning Create Shareholder Value? Access on the internet: https://papers.ssrn.com/sol3/papers.cfm?abstract_id=3176648

McKee, G., Froelich, K. (2016). Executive succession planning: Barriers and substitutes in non profit organizations. "Annals of Public and Cooperative Economics”, 87(4).

McLean, E., Scale, M. S., Rouse-Jones, M. D. (2016). Preparing tomorrow's library managers: Exploring leadership and succession planning at the University of the West Indies Libraries. Access on the internet: https://www.igi-global.com/chapter/preparing-tomorrows-librarymanagers/146490

Melton, L. C. (2018). Succession planning research in the educational sector. Access on the internet: https://link.springer.com/chapter/10.1007/978-3-319-72532-1_14

Menezes, K. A., Bhaskaran, S., Deswal, A. (2019). Effects of national culture on leadership succession planning in small-to-medium scale family enterprises. "International Journal of Entrepreneurship and Small Busines", 38(1-2).

Michel, A., Kammerlander, N. (2015). Trusted advisors in a family business's successionplanning process - An agency perspective. “Journal of Family Business Strategy”, 6(1).

Mihaylov, G., Zurbruegg, R. (2020). The relationship between financial risk management and succession planning in family businesses. "International Journal of Managerial Finance”. Advance Online Publication. DOI: 10.1108/IJMF-12-2019-0466

Mitchell, J. (2017). Succession Planning: An Imperative. “Law Prac.”, 43.

Moja, A. (2019). The use of family foundations for succession planning in Italy. "Trusts \& Trustees", 25(3).

Mokhber, M., Gi, T. G., Rasid, S. Z. A., Vakilbashi, A., Zamil, N. M., Seng, Y. W. (2017). Succession planning and family business performance in SMEs. "Journal of Management Development", 36(3).

Muhoho, J. E. (2014). Challenges facing human resources succession planning in Tanzania's work organizations: The case of public and private work organisations based in Dar es salaam region. "International Journal of Innovation and Scientific Research", 12(1).

Mulder, P. H. (2012). Family Business Succession: Planning Tools for S Corporations that Incorporate Asset and Divorce Protection. "Michigan Prob \& Est Plan J”, 32.

Muslim, S., Haron, S., Hashim, R., \& Hassan, N. (2015). Leadership development initiatives to ensure succession planning effectiveness. Access on the internet: https://link.springer. com/chapter/10.1007/978-981-4585-45-3_1 
Newhall, S. (2015). Aligning the talent development and succession planning processes: Don't allow critical leadership talent to fall by the wayside. "Development and Learning in Organizations: An International Journal”, 29(5).

Nicholson, L. A., Lashley, J. G. (2016). Succession Planning: The Caribbean Approach. Access on the internet: https://link.springer.com/chapter/10.1057/978-1-349-94879-6_3

Ntshangase, W. M., Ngiba, S. C., Van Niekerk, J. A., Zwane, E. M. (2016). The impact of succession planning on the sustainability of cane production by small-scale cane growers in the North Coast of Kwazulu-Natal, South Africa. "South African Journal of Agricultural Extension", 44(1).

Nyberg, A. J., Schepker, D. J., Cragun, O. R., Wright, P. M. (2017). Succession planning. Access on the internet: https://www.oxfordhandbooks.com/view/10.1093/oxfordhb/ 9780198758273.001.0001/oxfordhb-9780198758273-e-2

Okoro, C., Iheanachor, N. (2020). Talent Management and Succession Planning in Traditional Igbo Businesses. Access on the internet: https://www.emerald.com/insight/content/ doi/10.1108/S1877-636120200000026006/full/html

Opute, J. E. (2020). Succession Planning. Access on the internet: https://link.springer. com/chapter/10.1007/978-3-030-47128-6_5

Page, G., Gerstberger, R. (2019). Create a Sustainable Utility Through Workforce Development and Succession Planning. "Opflow”, 45(2).

Pandey, S., Sharma, D. (2014). Succession planning practices and challenges: study of Indian organisations. "Procedia Economics and Finance", 11.

Payne, R. A., Hovarter, R., Howell, M., Draws, C., Gieryn, D. (2018). Succession planning in public health: addressing continuity, costs, and compliance. "Nurse Leader", 16(4).

Perrenoud, A. J. (2020). Delphi Approach to Identifying Best Practices for Succession Planning within Construction Firms. "International Journal of Construction Education and Research", 16(3).

Perrenoud, A. J., Sullivan, K. T. (2017). Analysis of executive succession planning in 12 construction companies. "International Journal of Construction Education and Research", 13(1).

Peters-Hawkins, A. L., Reed, L. C., Kingsberry, F. (2018). Dynamic leadership succession: Strengthening urban principal succession planning. "Urban Education”, 53(1).

Pickering, C., Byrne, J. (2014). The benefits of publishing systematic quantitative literature reviews for PhD candidates and other early-career researchers. "Higher Education Research \& Development", 33(3).

Phillips, L. K. (2020). Concept analysis: Succession planning. Access on the internet: https://onlinelibrary.wiley.com/doi/abs/10.1111/nuf.12490

Phillips, T., Evans, J. L., Tooley, S., Shirey, M. R. (2018). Nurse manager succession planning: A cost-benefit analysis. "Journal of nursing management", 26(2).

Raftery, C. (2015). Succession planning for nurse practitioners. "The Journal for Nurse Practitioners", 11(2).

Ramadani, V., Hisrich, R. D., Anggadwita, G., \& Alamanda, D. T. (2017). Gender and succession planning: opportunities for females to lead Indonesian family businesses. "International Journal of Gender and Entrepreneurship", 9(3).

Rayburn, W., Grigsby, K., Brubaker, L. (2016). The strategic value of succession planning for department chairs. "Academic Medicine", 91(4). 
Reeves, T. J. (2018). Are You Preparing a Successor? Succession Planning in a Small, Private Practice, Healthcare Setting. Access on the internet: https://link.springer.com/chapter/ 10.1007/978-3-319-72532-1_13

Richins, S. M. (2018). Succession planning in non-profit healthcare organizations. Access on the internet: https://link.springer.com/chapter/10.1007/978-3-319-72532-1_5

Richman, L. I. (2012). Estate \& Succession Planning Corner. “J. Passthrough Entities”, 15.

Ritchie, M. (2020). Succession planning for successful leadership: Why we need to talk about succession planning! "Management in Education”, 34(1).

Ruffin, T. R. (2018). Strategies for healthcare organizations in succession planning. Access on the internet: https://link.springer.com/chapter/10.1007/978-3-319-72532-1_11

Russell, J. L., Sabina, L. L. (2014). Planning for principal succession: A conceptual framework for research and practice. "Journal of School Leadership", 24(4).

Sain, A., Koul, A. (2020). Assessing Leadership Development Strategies Adopted By The Organizations For Developing Internal Talent Pool. "Psychology and Education Journal", 57(9).

Santora, J. C. (2020). COVID-19: An urgent imperative for CEO succession planning. "Board Leadership", (170).

Savova, K. (2021). Global Impact of COVID 19 on the Concept of "Going Concern". Access on the internet: https://www.shs-conferences.org/articles/shsconf/pdf/2021/03/shsconf_ glob20_01045.pdf

Schaeffer, B. S., Akhavan, K. E. (2017). Succession planning for franchisees. "Franchise LJ', 36.

Schiuma, G., Durst, S., \& Wilhelm, S. (2012). Knowledge management and succession planning in SMEs. "Journal of Knowledge Management", 16(4).

Seaman, C., Welsh, R., Bent, R. (2013). Succession planning in minority ethnic family enterprises. "International Journal of Entrepreneurship and Small Business", 20(4).

Selig, B. (2020). Nurse Manager Interns: A Proactive Approach to Developing Leadership Talent and Solidifying Succession Planning. "Nurse leader", 18(6).

Sharma, A., Sengupta, T. (2018). Perspective on succession planning in multiple MNCs: interview with Aparna Sharma. "Human Resource Development International", 21(4).

Sharma, P., Chua, J. H., Chrisman, J. J. (2015). Succession Planning. Wiley Encyclopedia of Management, 1-4.

Sherrer, M., Rezania, D. (2020). A scoping review on the use and effectiveness of leadership coaching in succession planning, "International Journal of Theory, Research and Practice", 13(2).

Sierra, C. M., Calabrese, S. V. (2019). Succession planning for new practitioners. "American Journal of Health-System Pharmacy", 76(24).

Siewert, K. G., Louderback, P. (2019). The "Bus Proof” Library: Technical Succession Planning, Knowledge Transfer, and Institutional Memory. "Journal of Library Administration", 59(4).

Simpson, K., West, P. J. (2014). Succession planning and the talent management toolbox. Access on the internet: https://www.igi-global.com/chapter/succession-planning-and-thetalent-management-toolbox/99508

Sobel, K., Drewry, J. (2015). Succession planning for library instruction. "Public Services Quarterly", 11(2). 
Sonfield, M. C., Lussier, R. N., \& Fahed-Sreih, J. (2015). Planning for succession in family businesses: a comparison of Arab/Islamic and US practices. "International Journal of Business and Globalisation", 15(3).

Spina, L. J., Spina, J. D. (2020). Succession Planning for Sustainability. Access on the internet: https://www.emerald.com/insight/content/doi/10.1108/978-1-83909-996-020201017/ full/html

Sprague, J. (2019). Rotate Employees to Ease Succession Planning. “Opflow”, 45(3).

Staehr, A. E. (2015). Human resource risk and succession planning. "Agricultural Finance Review”, 75(1).

Tan-Atichat, L., Aiyeku, J. F. (2013). Strategies for Sustainable Succession Planning in Family Business. Access on the internet: https://www.igi-global.com/chapter/strategiessustainable-succession-planning-family/74465

Tao, R., Zhao, H. (2019). "Passing the Baton”: The effects of CEO succession planning on firm performance and volatility. "Corporate Governance: An International Review”, 27(1).

Tietjen-Smith, T., Hersman, B., Block, B. A. (2020). Planning for Succession: Preparing Faculty for the Kinesiology Department Head Role. "Quest”, 72(4).

Titzer, J. L., Shirey, M. R. (2013). Nurse manager succession planning: a concept analysis. Access on the internet: https://onlinelibrary.wiley.com/doi/abs/10.1111/nuf.12024

Trepanier, S., Crenshaw, J. T. (2013). Succession planning: a call to action for nurse executives. "Journal of Nursing Management", 21(7).

Tucker, C. A. (2020). Succession planning for academic nursing. "Journal of Professional Nursing”, 36(5).

Turner, P. (2018). Succession Planning and Leadership Development. Access on the internet: https://link.springer.com/chapter/10.1007/978-3-319-57888-0_7

Umans, I., Lybaert, N., Steijvers, T., Voordeckers, W. (2019). The influence of transgenerational succession intentions on the succession planning process: The moderating role of highquality relationships. “Journal of Family Business Strategy”, 100269.

Umans, I., Lybaert, N., Steijvers, T., Voordeckers, W. (2020). Succession planning in family firms: family governance practices, board of directors, and emotions. "Small Business Economics", 54(1).

Urban, B., Nonkwelo, R. P. (2020). Intra-family dynamics and succession planning in family businesses in South Africa: the daughter as a potential successor. "Journal of Family Business Management”. Advance Online Publication. DOI: 10.1108/JFBM-08-2020-0084

Varhegyi, M. M., Jepsen, D. M. (2017). Director succession planning in not-for-profit boards. “Asia Pacific Journal of Human Resources”, 55(1).

Vincent, W. S. (2017). Succession planning for the family-owned business. "GPSolo”, 34(5).

Vito, R. (2018). Leadership development in human services: Variations in agency training, organizational investment, participant satisfaction, and succession planning. "Human Service Organizations: Management, Leadership \& Governance", 42(3).

von Drathen, C. (2014). Do Chair Independence and Succession Planning Influence CEO Turnover? Access on the internet: https://papers.ssrn.com/sol3/papers.cfm?abstract_ id $=2536653$

Wadeson, D., Ciccotosto, S. (2013). Succession planning in small accounting practices in Regional Far North Queensland. “Australian Accounting Review”, 23(2).

Waxman, K. T., Delucas, C. (2014). Succession planning: Using simulation to develop nurse leaders for the future. "Nurse Leader", 12(5). 
Wealthadviser (2021). Significant rise in clients in Latin America requesting succession planning, reports ZEDRA. Access on the internet:https://www.wealthadviser.co/ 2020/04/17/284782/significant-rise-clients-latin-america-requesting-succession-planningreports

Weare, W. H. (2015). Succession planning in academic libraries: A reconsideration. Access on the internet: https://www.emerald.com/insight/content/doi/10.1108/S0732067120150000034013/full/html?utm_source=TrendMD\&utm_medium=cpc\&utm_campai gn=Advances_in_Library_Administration_and_Organization_TrendMD_0

Weisblat, I. A. (2018). Literature review of succession planning strategies and tactics. "Succession Planning", 11-22.

Wendee, P., Sussan, F., Chinta, R. (2018). An Epilogue to Succession Planning: Understanding the Value of Your Enterprise. Access on the internet: https://link.springer.com/chapter/ 10.1007/978-3-319-72532-1_18

Wilson, V. (2018). Succession planning models, conceptual maps: Ethical considerations and best practices. Access on the internet: https://link.springer.com/chapter/10.1007/978-3-31972532-1_16

Winship, K. (2012). Knowledge capture and the retirement of the director of finance: Succession planning in the San Mateo county human services agency. "Journal of evidence-based social work", 9(1-2).

World Health Organisation (2021). WHO Corona Virus (COVID-19) Dashboard. Access on the internet: https://covid19.who.int/

Worldometer (2021). Countries in the World: 195. Access on the internet:https://www. worldometers.info/geography/how-many-countries-are-there-in-the-world/

Wright, L. (2015). Succession Planning - How to Be an Honest Talent Broker. Access on the internet: https://link.springer.com/chapter/10.1057/9781137450913_7

Yadav, S. S., Shankar, R. (2017). Succession planning: some lessons. "Journal of Advances in Management Research", 14(4).

Yucedag-Ozcan, A., \& Metcalfe, S. K. (2018). Case studies in succession planning for K12 districts. Access on the internet: https://link.springer.com/chapter/10.1007/978-3-31972532-1_15

Zeidan, S., Itani, N. (2020). Cultivating employee engagement in organizations: development of a conceptual framework. "Central European Management Journal", 28(1).

Zepeda, S. J., Bengtson, E., Parylo, O. (2012). Examining the planning and management of principal succession. "Journal of Educational Administration”, 50(2).

DOI: $10.7862 / \mathrm{rz} .2021 . \mathrm{mmr} .26$

The text was submitted to the editorial office: August 2021.

The text was accepted for publication: December 2021. 